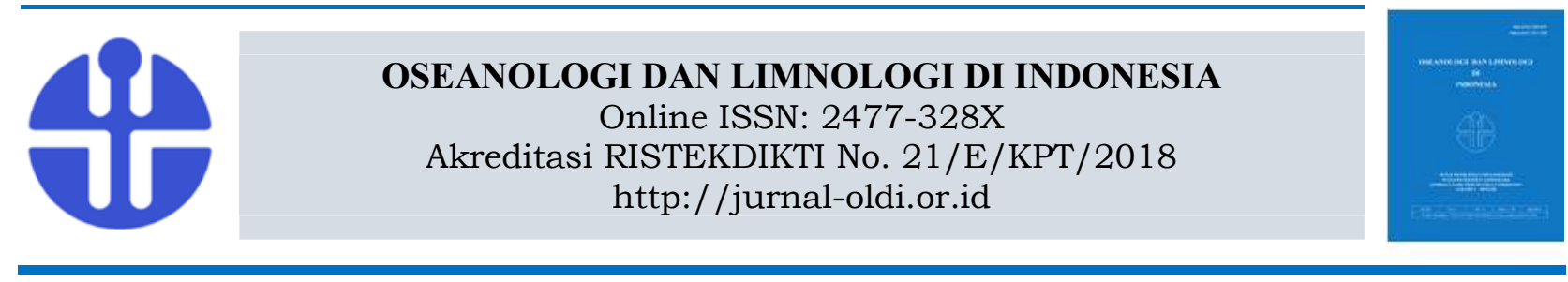

\title{
Pengaruh Konsentrasi Nutrien Terhadap Kelimpahan Fitoplankton di Perairan Halmahera- Maluku
}

\author{
Hanny Meirinawati dan Nurul Fitriya \\ Pusat Penelitian Oseanografi - LIPI, Jl. Pasir Putih I, Ancol Timur, Jakarta 14430 \\ Email: hanny.meirinawati@gmail.com; nurulfitriya29@gmail.com
}

Submitted 15 May 2018. Reviewed 28 August 2018. Accepted 22 October 2018

DOI: $10.14203 /$ oldi.2018.v3i3.129

\begin{abstract}
Abstrak
Ketersediaan nutrien di laut sangat penting untuk pertumbuhan dan akumulasi biomassa fitoplankton. Masukan nutrien yang menyebabkan perubahan rasionya akan mempengaruhi komposisi spesies komunitas fitoplankton beserta biota yang tingkat tropiknya lebih tinggi. Pengaruh nutrien terhadap kelimpahan fitoplankton sangat penting untuk dikaji karena fungsinya sebagai faktor pembatas bagi pertumbuhan fitoplankton. Selain itu, kedua variabel tersebut merupakan faktor penting dalam menenetukan produktivitas suatu perairan. Penelitian ini bertujuan untuk menganalisis komposisi dan kelimpahan fitoplankton serta hubungannya dengan nutrien anorganik terlarut di Laut Halmahera-Maluku. Penelitian dilakukan pada Bulan November 2015 di 8 stasiun sampling Laut Halmahera-Maluku. Parameter kualitas air yang diukur yaitu $\mathrm{pH}$ menggunakan metode potensiometri, oksigen terlarut (DO) menggunakan metode titrimetri, serta nitrat, nitrit, amonium, fosfat, dan silikat yang diukur menggunakan metode kolorimetri. Fitoplankton diambil dengan menyaring air dari Rosette sampler dengan menggunakan hand plankton net ukuran mata jaring 20 $\mu \mathrm{m}$. Komposisi dan kelimpahan fitoplankton ditentukan melalui pengamatan mikroskopis. Hasil penelitian menunjukkan bahwa amonium secara signifikan berkorelasi positif dengan kelimpahan fitoplankton $(\mathrm{r}=0,9133$ pada $\mathrm{p}<0,01)$. Hubungan antara nutrien dengan fitoplankton menjelaskan bahwa setiap genus memiliki preferensi terhadap nutrien yang berbeda. Keberadaan amonium secara signifikan meningkatkan kelimpahan fitoplankton dari genus Chaetoceros, Nitzchia, Climacodium, Ceratium, Eucampia, Lauderia, Protoperidinium, dan Rhizosolenia. Lain hal nya dengan ammonium, fosfat dapat meningkatkan kelimpahan fitoplankton dari genus Coscinodiscus meskipun tidak secara signifikan. Selain itu, silikat dapat meningkatkan kelimpahan fitoplankton dari genus Thalassiothrix, Bacteriastrum, Skletonema, dan Hemiaulus sedangkan nitrat dapat meningkatkan kelimpahan fitoplankton dari genus Alexandrium.
\end{abstract}

Kata Kunci: Nutrien, Fitoplankton, Kelimpahan, Halmahera

\begin{abstract}
Effects of Nutrients Concentration on Phytoplankton Abundance in The Halmahera-Molucca Sea. The availability of nutrients in the ocean is essential for the growth and accumulation of phytoplankton biomass. The input nutrients can then changes its ratio which may affect the species composition of phytoplankton communities and higher trophic level biotas. The effects of nutrients on phytoplankton
\end{abstract}




\section{Meirinawati \& Fitriya}

abundance are very important to be studied due to its role as limiting factors for phytoplankton growth. Besides that, these two variables are most important factors in measuring aquatic productivity. This study aims to analyzed composition and abundance of phytoplankton and its relationship with dissolved inorganic nutrients in the Halmahera-Molucca Sea. This research was conducted in November 2015 covering 8 sampling station within the Halmahera-Molucca Sea. Water quality parameters, such as $\mathrm{pH}$ was measured using potentiometic method, dissolved oxygen (DO was measured using titrimetric method), and nitrate, nitrite, ammonium, phosphate and silicate, were measured using the colorimetric method. The water samples were taken using Rosette sampler and then filtered using hand net plankton with size $20 \mu \mathrm{m}$ to obtain the phytoplankton. Plankton composition and abundance were then determined by microscopic analysis. The result showed that ammonium positively correlated with phytoplankton abundance $(\mathrm{r}=0.9133$ at $\mathrm{p}<0.01)$. The correlation between nutrients and phytoplankton show that each genus has a preference for different nutrients. The presence of ammonium significantly increase the phytoplankton abundance from genus Chaetoceros, Nitzchia, Climacodium, Ceratium, Eucampia, Lauderia, Protoperidinium, and Rhizosolenia. On the other hand, phosphates increase the phytoplankton abundance from genus Coscinodiscus although not significantly. Besides, silicates increase the phytoplankton abundance from genus Thalassiothrix, Bacteriastrum, Skletonema, and Hemiaulus while nitrates increase the phytoplankton abundance from genus Alexandrium.

Keywords: Nutrients, phytoplankton, abundance, Halmahera

\section{Pendahuluan}

Perairan Laut Halmahera merupakan perairan dengan potensi perikanan yang besar di Indonesia dibuktikan dengan melimpahnya jumlah ikan pelagis besar, ikan pelagis kecil dan ikan demersal (Tangke et al. 2015). Hal tersebut didukung oleh kondisi fisika-kimia perairan yang sesuai untuk pertumbuhan fitoplankton sebagai sumber pakan ikan seperti suhu permukaan yang berkisar antara $27,718{ }^{\circ} \mathrm{C}$ dan $28,955{ }^{\circ} \mathrm{C}$ serta salinitas yang bervariasi antara 33,742-34,551 psu (Pusat Penelitian Oseanografi 2005). Fitoplankton memiliki peran sebagai produsen primer yang penting terutama dalam rantai makanan dalam ekosistem laut. Selain itu, fitoplankton berperan terhadap kesuburan laut ini distribusi spasialnya dipengaruhi oleh arus dan cahaya (Millero 2006). Dilihat dari kelimpahan fitoplankton di perairan barat Halmahera, kelompok diatom lebih dominan dibanding dinoflagellata. Genera diatom yang mempunyai frekuensi kejadian lebih dari $90 \%$ yaitu Chaetoceros, Coscinodiscus, Ditylumsol, Skeletonema dan Thalassiothrix (Pusat Penelitian Oseanografi 2005). Kondisi fisik dan kelimpahan fitoplankton tersebut menunjukkan variabilitas yang dinamis di Laut Halmahera. Komposisi fitoplankton juga akan dipengaruhi oleh proses upwelling, tercatat selama musim timur komposisi fitoplankton lebih bervariasi dibandingkan musim peralihan. Fenomena upwelling di perairan Indonesia terjadi di perairan Banda pada musim timur yang teramati pada bulan Agustus 1997 (Sediadi 2004).
Faktor penting lain yang berpengaruh dalam pertumbuhan dan akumulasi biomassa fitoplankton di laut adalah ketersediaan nutrien (Struyf et al. 2009). Nutrien merupakan senyawa yang mengandung unsur N, P, dan Si yang sangat dibutuhkan oleh organisme laut dalam metabolisme, proses fisiologis, dan reaksi biokimiawi (Riley and Chester 1971; Chen 2007). Konsentrasi nutrien perairan dipengaruhi oleh masukan dari daratan yang kemudian dimanfaatkan untuk pertumbuhan fitoplankton (Koike et al. 2001). Sumber utama nutrien di laut berasal dari pelapukan batu, pembusukan material organik dan limbah akibat aktivitas manusia yang dibawa oleh sungai menuju laut. Proses percampuran massa air secara vertikal di lautan juga akan menyebabkan konsentrasi nutrien yang berada di lapisan dalam terangkat ke lapisan eufotik (Sediadi 2004). Variasi temporal dan spasial konsentrasi nutrien dapat mempengaruhi struktur komunitas fitoplankton dan produktivitas primer di ekosistem laut ( $\mathrm{Zhu}$ et al. 2010). Masukan nutrien dapat menyebabkan perubahan dalam rasionya yang berpengaruh terhadap komposisi spesies fitoplankton dan biota yang tingkat trofiknya yang lebih tinggi (Turner, 2002). Rasio N:P sebesar 16:1 merupakan indikator yang digunakan sebagai pembatas nutrien dan status ekosistem (Li et al. 2012).

Variasi konsentrasi nutrien dan kelimpahan fitoplankton dapat menjadi pendekatan dalam melakukan tinjauan profil kesuburan perairan (Millero 2006). Tinjauan ini menjadi cukup penting terutama pada perairan laut Halmahera 
yang memiliki produksi perikanan yang sangat potensial. Oleh karena itu, penelitian ini dilakukan untuk menganalisis komposisi dan kelimpahan fitoplankton serta hubungannya dengan nutrien anorganik terlarut di Laut Halmahera-Maluku.

\section{Metodologi}

\section{Lokasi Penelitian}

Penelitian ini dilakukan pada bulan November 2015 dengan menggunakan Kapal Riset Baruna Jaya VIII. Pengambilan sampel untuk nutrien dan fitoplankton dilakukan pada 8 stasiun yang tersebar di perairan HalmaheraMaluku (Tabel 1 dan Gambar 1).

\section{Pengukuran DO, pH, dan Kadar Nutrien}

Parameter fisika-kimia yang diukur dalam studi ini adalah DO, $\mathrm{pH}$ dan kadar nutrien (silikat, nitrat, nitrit, amonium dan ortofosfat). Pengukuran parameter tersebut dilakukan langsung di lapangan untuk meminimalkan bias hasil pengukuran. Oleh karena itu, selama di lapangan, sebanyak $500 \mathrm{~mL}$ sampel air laut diambil menggunakan Rosette Sampler dari lapisan permukaan laut kemudian dimasukkan ke dalam botol polietilena. Setelah sampel air laut didapat, oksigen terlarut (DO) diukur dengan metode Winkler dan $\mathrm{pH}$ diukur dengan menggunakan $\mathrm{pH}$ meter tipe $\mathrm{pHTestr} 20^{\circledR}$. Untuk analisis nutrien, sampel air disaring dengan menggunakan kertas saring nitroselulosa berdiameter pori $0,45 \mu \mathrm{m}$ dan diameter $47 \mathrm{~mm}$. Setelah itu, nutrien dianalisis menggunakan metode spektrofotometri dengan alat spektrofotometer Shimadzu UV-1800 dengan beberapa panjang gelombang yang berbeda. Fosfat diukur pada panjang gelombang $885 \mathrm{~nm}$, nitrat dan nitrit pada panjang gelombang $543 \mathrm{~nm}$, sedangkan ammonium dan silikat diukur masingmasing pada panjang gelombang $640 \mathrm{~nm}$ dan 810 $\mathrm{nm}$. Konsentrasi DIN (Dissolved Inorganic Nitrogen) diperoleh dari penambahan konsentrasi nitrat, nitrit, dan amonium sedangkan DIP merupakan konsentrasi dari ortofosfat (Strickland and Parsons, 1972).

\section{Pengambilan, Pengawetan dan Pengamatan Sampel Plankton}

Sampel air yang diambil kemudian disaring dengan menggunakan hand plankton net ukuran mata jaring $20 \mu \mathrm{m}$. Filtrat yang terkumpul di bucket lalu dimasukkan ke dalam botol sampel
$250 \mathrm{ml}$ dan difiksasi dengan formaldehida $4 \%$. Selanjutnya botol sampel diberikan label data nomor stasiun, lokasi pengambilan, tipe alat, hari dan waktu pengambilan sampel.

Sampel yang diperoleh selanjutnya diidentifikasi di P2O LIPI Jakarta menggunakan mikroskop dengan bantuan beberapa buku identifikasi antara lain Davis (1955), Wickstead (1965), Yamaji (1976), Taylor (1994), dan Omura et al. (2012). Pencacahan fitoplankton secara kualitatif dilakukan dengan menggunakan Sedgwick rafter counting cell atas fraksi sampel dan hasilnya dinyatakan dalam sel. $\mathrm{m}^{-3}$; Kelimpahan fitoplankton dihitung dengan menggunakan rumus sebagai berikut:

$$
\begin{array}{ll}
\mathrm{N}= & \mathrm{n} \times \frac{\mathrm{Vt}}{\mathrm{Vs}} \times \frac{1}{\mathrm{~V}} \\
\mathrm{~N}= & \text { Jumlah total plankton } \\
\mathrm{Vt}= & \text { Volume sampel } \\
\mathrm{Vs}= & \text { Volume sub sampel (fraksi) } \\
\mathrm{V}= & \text { Volume air tersaring } \\
\mathrm{n}= & \text { Jumlah plankton yang tercacah pada sub- } \\
& \text { sampel }
\end{array}
$$

\section{Analisis Statistik}

Analisis statistik dilakukan dengan menggunakan software SPSS 17. Korelasi antara kelimpahan fitoplankton dengan parameter kualitas air ditentukan dengan menggunakan korelasi Pearson. Hubungan antara nutrien dengan genus fitoplankton dianalisis dengan menggunakan PCA (Principal Component Analysis).

Tabel 1. Posisi stasiun penelitian di Laut Halmahera-Maluku.

Table 1. Research station position in HalmaheraMolucca Sea.

\begin{tabular}{|c|c|c|}
\hline St & Long & Lat \\
\hline 1 & 126.80332 & -1.7976 \\
\hline 2 & 129.24008 & -0.1242833 \\
\hline 3 & 129.07217 & -0.0256333 \\
\hline 4 & 128.96105 & 0.0867167 \\
\hline 5 & 127.3016 & 1.99995 \\
\hline 6 & 126.48453 & 1.9776833 \\
\hline 7 & 126.11657 & 1.9988167 \\
\hline 8 & 125.70047 & 1.9962167 \\
\hline
\end{tabular}




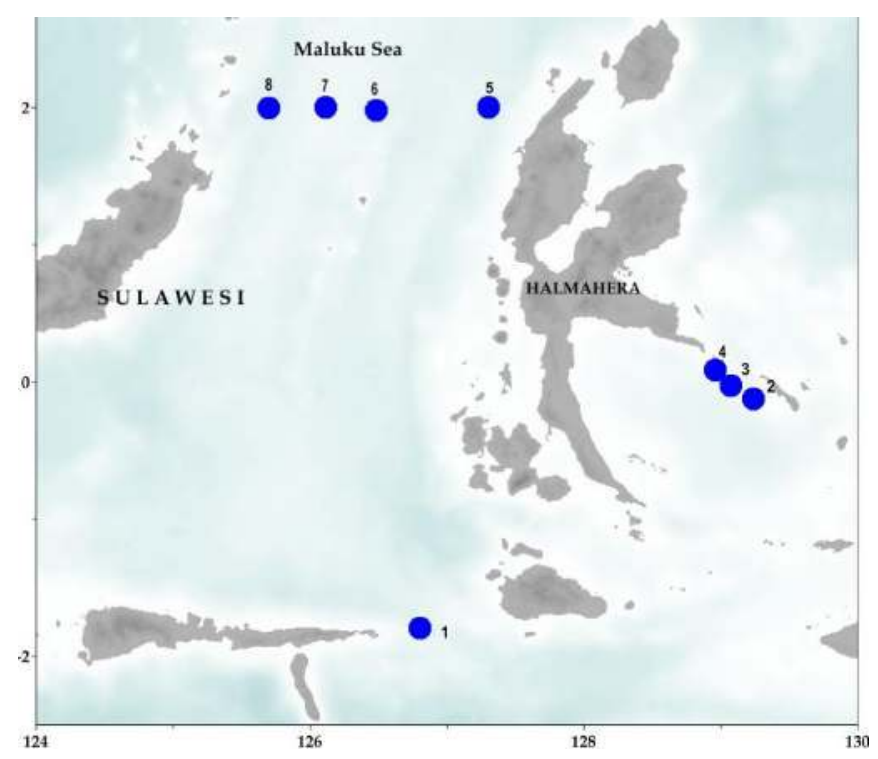

Gambar 1. Lokasi penelitian di Laut Halmahera-Maluku, November 2015.

Figure 1. Sampling sites in Halmahera-Molucca Sea, November 2015.

\section{Hasil}

Hasil pengukuran kualitas perairan yaitu $\mathrm{pH}, \mathrm{DO}$, fosfat, DIN, dan silika di laut Halmahera-Maluku disajikan pada Tabel 2. Nilai $\mathrm{pH}$ tidak menunjukkan variasi yang mencolok yaitu berkisar antara 7,79-8,24 dengan rata-rata 7,91. Tujuh dari delapan stasiun memiliki $\mathrm{pH}$ di bawah angka 8 dengan deviasi yang sempit sedangkan variasi lebih tinggi teramati di stasiun 1 dengan $\mathrm{pH} 8,24$. DO juga menunjukkan variasi yang kecil dengan nilai antara 5,89-6,50 $\mathrm{mg} / \mathrm{L}$ dan rata-rata $6,12 \mathrm{mg} / \mathrm{L}$. Nilai DO tertinggi berada di stasiun 7 dan terendah di stasiun 2. Konsentrasi fosfat, yang terukur sebesar 0,004-0,007 mg/L dan uniknya lima stasiun memiliki nilai fosfat sebesar $0,004 \mathrm{mg} / \mathrm{L}$. Nilai fosfat tertinggi dengan nilai $0,007 \mathrm{mg} / \mathrm{L}$ ditunjukkan oleh dua stasiun (stasiun 2 dan 7). Berbeda dengan fosfat, silikat memiliki rentangan nilai yang relatif lebih lebar yaitu antara $0,063-0,159 \mathrm{mg} / \mathrm{L}$ dengan rerata $0,111 \mathrm{mg} / \mathrm{L}$. Konsentrasi silikat tertinggi berada di stasiun 8 dan terendah di stasiun 6. Setelah nilai tiap nutrien didapat, dilakukan perhitungan lebih lanjut untuk mengetahui kadar nitrogen anorganik terlarut (DIN).

DIN merupakan representasi dari nitrat, nitrit dan ammonium sehingga fluktuasi ketiga unsur tersebut akan mempengaruhi nilai DIN. Hasil perhitungan menunjukkan bahwa nilai DIN berkisar antara 0,026-0,088 $\mathrm{mg} / \mathrm{L}$, dengan nilai rata-rata $0,060 \mathrm{mg} / \mathrm{L}$. Unsur nitrat merupakan parameter yang paling banyak memberikan kontribusi terhadap nilai DIN karena konsentrasi nitrat relatif lebih tinggi dibandingkan dengan nitrit dan ammonium. Dilihat dari distribusinya, konsentrasi DIN tertinggi berada di stasiun 6 dan terendah di stasiun 3 .

Perhitungan lain yang telah dilakukan dalam studi ini adalah perhitungan rasio DIN:DIP dan rasio DIP:Si sehingga diketahui faktor pembatas pertumbuhan fitoplankton di perairan Halmahera-Maluku. Hasil perhitungan menunjukkan bahwa rasio DIN:DIP memiliki rentangan nilai yang lebih lebar dibandingkan DIN:Si. Rasio DIN:DIP berkisar antara 4,3821,28 dengan rata-rata 12,61. Rasio DIN:DIP tertinggi berada di stasiun 6 dan terendah di stasiun 2. Rasio DIN:Si berkisar antara 0,2591,403 dengan rata-ratanya 0,610 . Rasio DIN:Si tertinggi berada di stasiun 6 dan terendah di stasiun 3 .

\section{Kelimpahan Plankton}

Fitoplankton yang berhasil diidentifikasi terdiri atas dua kelas dan 23 genus, yaitu 15 genus Bacillariophyceae/Diatom dan delapan genus Dynophyceae/Dinoflagellata. Kelimpahan fitoplankton berkisar antara 721.500-9.100.000 sel. $\mathrm{m}^{-3}$ dengan kelimpahan tertinggi di stasiun 4 dan kelimpahan terendah di stasiun 5 (Gambar 2).

Gambar 3 menunjukkan komposisi fitoplankton yang lebih didominasi oleh kelompok 
Oseanologi dan Limnologi di Indonesia 2018 3(3): 183-195

Diatom dari genus Chaetoceros (53\%), Rhizosolenia (11\%), dan Bacteriastrum (11\%). Genus Chaetoceros memiliki kelimpahan tertinggi di semua stasiun. Demikian juga dalam kelompok Diatom itu sendiri (Gambar 4) komposisi Diatom terbesar didominasi oleh genus Chaetoceros (57\%), Rhizosolenia (12\%) dan Bacteriastrum (11\%). Genus ini umum dijumpai sering mendominasi di perairan Indonesia sedangkan kelas Dinophyceae didominasi oleh Alexandrium (51\%) dan Prorocentrum (25\%) (Gambar 5).

\section{Pengaruh nutrien terhadap kelimpahan fitoplankton}

Berdasarkan analisis PCA yang disajikan pada Gambar 8 menunjukkan bahwa amonium, fosfat, dan silikat lebih berpengaruh terhadap berbagai genus fitoplankton dibandingkan nitrat yang cenderung lebih mempengaruhi genus Alexandrium dan Dinophysis. Amonium berpengaruh terhadap kelimpahan genus Chaetoceros, Nitzchia, Climacodium, Ceratium, Eucampia, Lauderia, Protoperidinium, Rhizosolenia, Coscinodiscus dan Prorocentrum. Adapun fosfat memberi pengaruh terhadap genus yang sama dengan amonium, sedangkan silikat mempengaruhi kelimpahan dari genus Thalassiothrix, Bacteriastrum, Skletonema, Hemiaulus, Guinardia, Pyrophacus, dan Thalassiosira. Hal ini diperkuat dari hasil korelasi antara fitoplankton dan nutrien (Tabel 2) meskipun tidak semua genus berkorelasi secara signifikan dengan nutrien. Dari hasil korelasi diketahui bahwa: amonium berkorelasi signifikan terhadap Chaetoceros $(\mathrm{p}<0,01 ; \mathrm{r}=0,91)$, Nitzchia $(\mathrm{p}<0,05 ; \mathrm{r}=0,83)$, Climacodium $(\mathrm{p}<0,01 ; \mathrm{r}=0,94)$, Ceratium ( $\mathrm{p}<0,01 ; \mathrm{r}=0,94)$, Eucampia $(\mathrm{p}<0,01$; $\mathrm{r}=0,85), \quad$ Lauderia $\quad(\mathrm{p}<0,01 ; \quad \mathrm{r}=0,85)$, Protoperidinium $(\mathrm{p}<0,05 ; 0,74)$, dan Rhizosolenia $(\mathrm{p}<0,05 ; \mathrm{r}=0,80)$. Fosfat memiliki pengaruh terhadap Coscinodiscus dengan korelasi yang tidak cukup signifikan $(\mathrm{r}=0,64 ; \mathrm{p}<0,10)$. Sementara itu, silikat memiliki pengaruh terhadap Thalassiothrix, Bacteriastrum, Skletonema, dan Hemiaulus. Bacteriastrum $\quad(\mathrm{r}=0,67)$, Thalassiothrix $\quad(\mathrm{r}=0,65), \quad$ Skletonema $\quad(\mathrm{r}=0,63)$ memiliki korelasi tidak cukup signifikan dengan silikat pada $\mathrm{p}<0,10$. Kemudian, nitrat juga memiliki pengaruh terhadap Alexandrium, namun tidak cukup signifikan $(\mathrm{r}=0,61 ; \mathrm{p}<0,10)$.

Tabel 2. Kualitas perairan di Laut Halmahera-Maluku.

Table 2. Water quality in Halmahera-Molucca Sea.

\begin{tabular}{|c|c|c|c|c|c|c|c|c|c|c|}
\hline \multirow{3}{*}{ Station } & \multicolumn{10}{|c|}{ Parameters of Water Quality } \\
\cline { 2 - 13 } & $\mathrm{pH}$ & $\begin{array}{c}\mathrm{DO} \\
(\mathrm{mg} / \mathrm{L})\end{array}$ & $\begin{array}{c}\mathrm{SiO}_{3} \\
(\mathrm{mg} / \mathrm{L})\end{array}$ & $\begin{array}{c}\mathrm{PO}_{4} \\
(\mathrm{mg} / \mathrm{L})\end{array}$ & $\begin{array}{c}\mathrm{NO}_{3} \\
(\mathrm{mg} / \mathrm{L})\end{array}$ & $\begin{array}{c}\mathrm{NO}_{2} \\
(\mathrm{mg} / \mathrm{L})\end{array}$ & $\begin{array}{c}\mathrm{NH}_{3} \\
(\mathrm{mg} / \mathrm{L})\end{array}$ & $\begin{array}{c}\text { DIN } \\
(\mathrm{mg} / \mathrm{L})\end{array}$ & $\begin{array}{c}\text { DIN:D } \\
\text { IP }\end{array}$ & DIN:Si \\
\hline 1 & 8.24 & 6.03 & 0.146 & 0.004 & 0.052 & 0.004 & 0.006 & 0.063 & 15.18 & 0.429 \\
\hline 2 & 7.84 & 5.89 & 0.109 & 0.007 & 0.024 & 0.004 & 0.004 & 0.032 & 4.38 & 0.295 \\
\hline 3 & 7.86 & 6.09 & 0.100 & 0.004 & 0.018 & 0.005 & 0.003 & 0.026 & 6.29 & 0.259 \\
\hline 4 & 7.79 & 6.17 & 0.126 & 0.006 & 0.040 & 0.005 & 0.025 & 0.070 & 12.27 & 0.560 \\
\hline 5 & 7.85 & 6.06 & 0.100 & 0.004 & 0.065 & 0.005 & 0.003 & 0.073 & 17.65 & 0.727 \\
\hline 6 & 7.88 & 6.30 & 0.063 & 0.004 & 0.074 & 0.006 & 0.008 & 0.088 & 21.28 & 1.403 \\
\hline 7 & 7.88 & 6.50 & 0.084 & 0.007 & 0.061 & 0.004 & 0.005 & 0.070 & 9.56 & 0.836 \\
\hline 8 & 7.90 & 5.95 & 0.159 & 0.004 & 0.043 & 0.005 & 0.010 & 0.059 & 14.24 & 0.371 \\
\hline
\end{tabular}


Meirinawati \& Fitriya

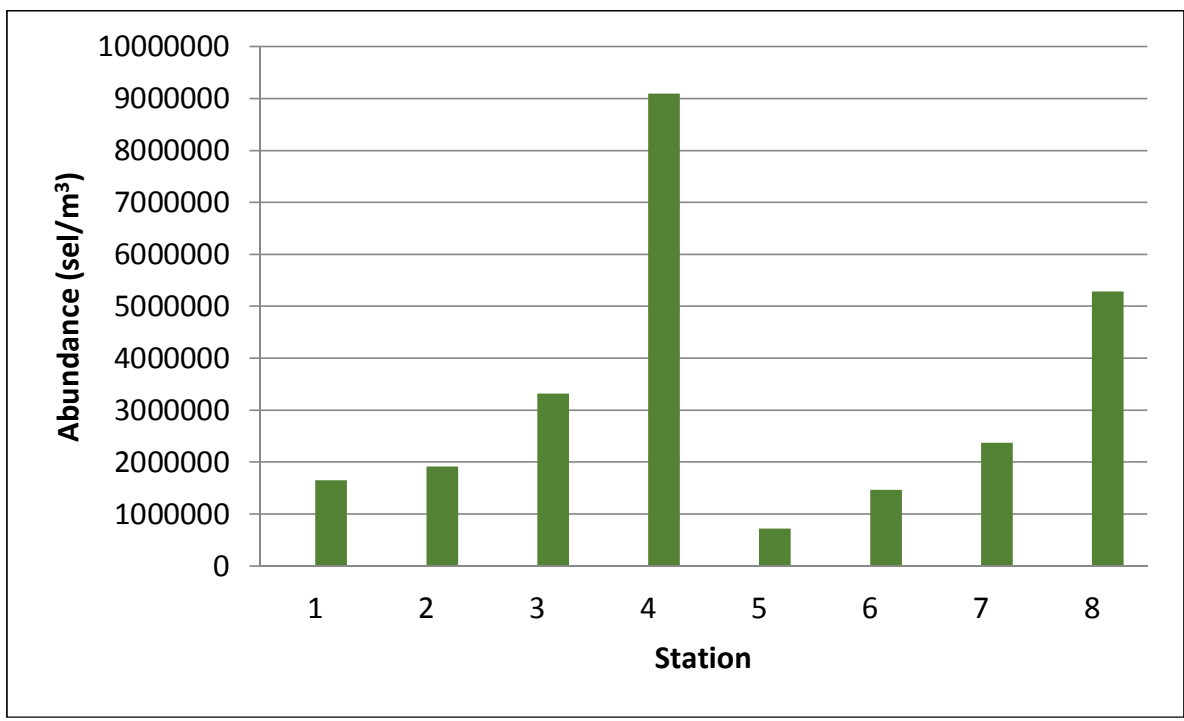

Gambar 2. Kelimpahan fitoplankton di delapan stasiun.

Figure 2. Phytoplankton abundance at eight sampling sites.

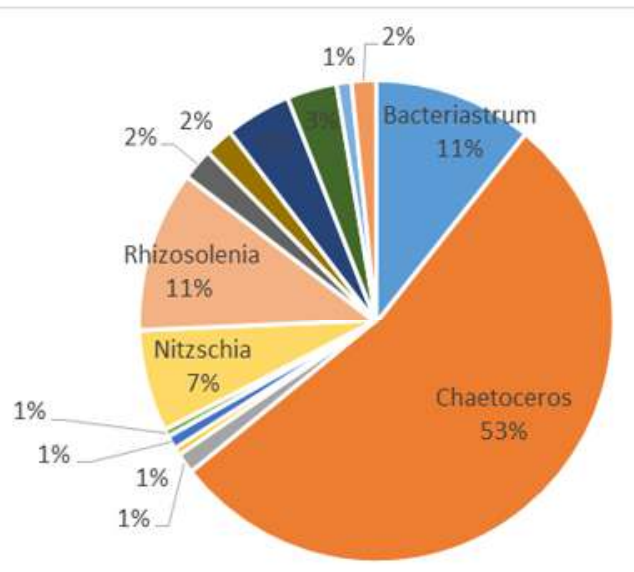

Gambar 3. Komposisi fitoplankton di delapan stasiun.

Figure 3. Phytoplankton composition at eight sampling sites.

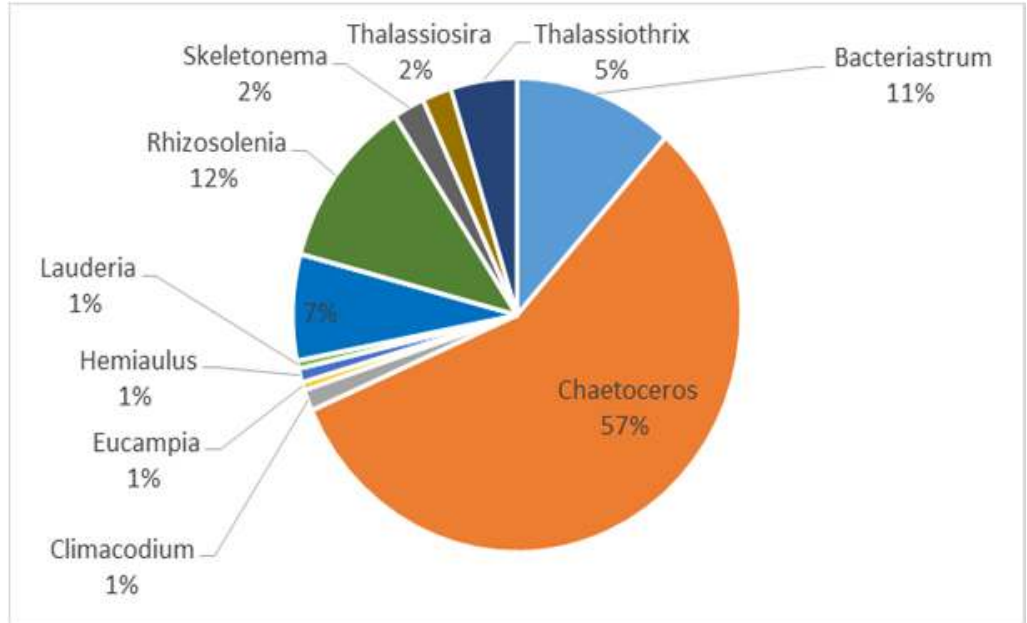

Gambar 4. Komposisi Bacillariophyceae di delapan stasiun.

Figure 4. Bacillariophyceae composition at eight sampling sites. 
Oseanologi dan Limnologi di Indonesia 2018 3(3): 183-195

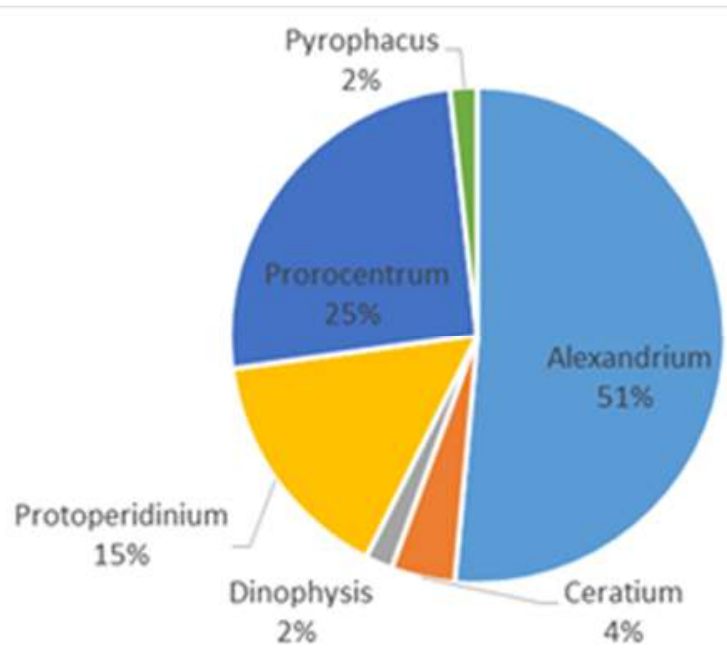

Gambar 5. Komposisi Dinophyceae di delapan stasiun.

Figure 5. Dinophyceae Composition at eight sampling sites.

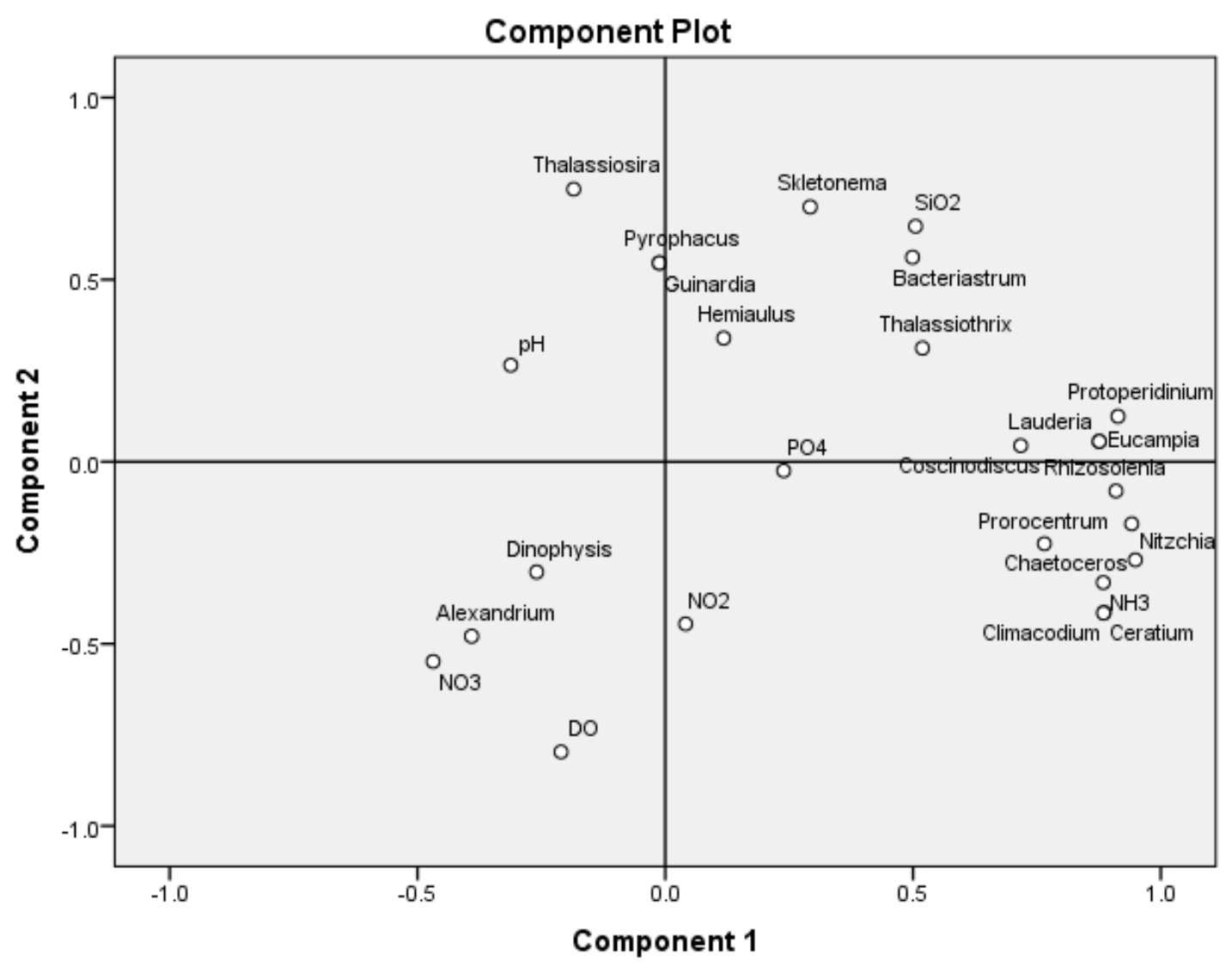

Gambar 8. Analisis PCA antara fitoplankton dengan parameter kualitas air. Figure 8. PCA analysis between phytoplankton and water quality parameter. 
Tabel 2. Korelasi antara parameter kualitas air dengan kelimpahan fitoplankton.

Table 2 . Correlation between water quality parameter and phytoplankton abundance.

\begin{tabular}{|c|c|c|c|c|c|}
\hline & & $\mathrm{SiO}_{2}$ & $\mathrm{PO}_{4}$ & $\mathrm{NO}_{3}$ & $\mathrm{NH}_{3}$ \\
\hline \multirow[t]{3}{*}{ Bacteriastrum } & Pearson Correlation & .677 & -.228 & -.456 & .287. \\
\hline & Sig. (2-tailed) & .065 & .586 & .256 & .490 \\
\hline & $\mathrm{N}$ & 8 & 8 & 8 & 8 \\
\hline \multirow[t]{3}{*}{ Chaetoceros } & Pearson Correlation & .332 & .246 & -.295 & $.909^{* *}$ \\
\hline & Sig. (2-tailed) & .421 & .557 & .478 & .002 \\
\hline & $\mathrm{N}$ & 8 & 8 & 8 & 8 \\
\hline \multirow[t]{3}{*}{ Climacodium } & Pearson Correlation & .193 & .286 & -.146 & $.942^{* *}$ \\
\hline & Sig. (2-tailed) & .647 & .493 & .729 & .000 \\
\hline & $\mathrm{N}$ & 8 & 8 & 8 & 8 \\
\hline \multirow[t]{3}{*}{ Eucampia } & Pearson Correlation & .589 & .033 & -.179 & $.850^{* *}$ \\
\hline & Sig. (2-tailed) & .125 & .937 & .671 & .008 \\
\hline & $\mathrm{N}$ & 8 & 8 & 8 & 8 \\
\hline \multirow[t]{3}{*}{ Lauderia } & Pearson Correlation & .589 & .033 & -.179 & $.850^{* *}$ \\
\hline & Sig. (2-tailed) & .125 & .937 & .671 & .008 \\
\hline & $\mathrm{N}$ & 8 & 8 & 8 & 8 \\
\hline \multirow[t]{3}{*}{ Nitzchia } & Pearson Correlation & .252 & .353 & -.532 & $.826^{*}$ \\
\hline & Sig. (2-tailed) & .547 & .392 & .175 & .012 \\
\hline & $\mathrm{N}$ & 8 & 8 & 8 & 8 \\
\hline \multirow[t]{3}{*}{ Rhizosolenia } & Pearson Correlation & .488 & .243 & -.482 & $.799^{*}$ \\
\hline & Sig. (2-tailed) & .220 & .562 & .226 & .017 \\
\hline & $\mathrm{N}$ & 8 & 8 & 8 & 8 \\
\hline \multirow[t]{3}{*}{ Skletonema } & Pearson Correlation & .629 & -.085 & -.246 & .128 \\
\hline & Sig. (2-tailed) & .095 & .841 & .556 & .762 \\
\hline & $\mathrm{N}$ & 8 & 8 & 8 & 8 \\
\hline \multirow[t]{3}{*}{ Thalassiothrix } & Pearson Correlation & .645 & -.023 & -.059 & .472 \\
\hline & Sig. (2-tailed) & .084 & .957 & .890 & .237 \\
\hline & $\mathrm{N}$ & 8 & 8 & 8 & 8 \\
\hline \multirow[t]{3}{*}{ Coscinodiscus } & Pearson Correlation & .141 & .635 & -.453 & .616 \\
\hline & Sig. (2-tailed) & .739 & .090 & .259 & .104 \\
\hline & $\mathrm{N}$ & 8 & 8 & 8 & 8 \\
\hline \multirow[t]{3}{*}{ Alexandrium } & Pearson Correlation & -.653 & -.206 & .606 & -.024 \\
\hline & Sig. (2-tailed) & .079 & .624 & .111 & .955 \\
\hline & $\mathrm{N}$ & 8 & 8 & 8 & 8 \\
\hline \multirow[t]{3}{*}{ Ceratium } & Pearson Correlation & .192 & .284 & -.144 & $.941^{* *}$ \\
\hline & Sig. (2-tailed) & .649 & .496 & .734 & .000 \\
\hline & $\mathrm{N}$ & 8 & 8 & 8 & 8 \\
\hline \multirow[t]{3}{*}{ Protoperidinium } & Pearson Correlation & .447 & .362 & -.627 & $.741^{*}$ \\
\hline & Sig. (2-tailed) & .267 & .378 & .096 & .036 \\
\hline & $\mathrm{N}$ & 8 & 8 & 8 & 8 \\
\hline
\end{tabular}

*. Correlation is significant at the 0.05 level (2-tailed).

**. Correlation is significant at the 0.01 level (2-tailed). 


\section{Pembahasan}

\section{Profil Nutrien di Perairan Halmahera-Maluku}

Penelitian ini memperlihatkan variasi pada

tiap parameter fisika-kimia di tiap stasiun sehingga menyebabkan beragamnya kelimpahan fitoplankton. Kondisi fisika-kimia air laut seperti pH dan DO di Perairan Halmahera-Maluku tidak menunjukkan perbedaan nilai yang mencolok dan tergolong normal di perairan laut lepas. Kedua parameter tersebut termasuk faktor pendukung utama bagi pertumbuhan fitoplankton. Berge et al. (2010) menyebutkan bahwa laju pertumbuhan optimum untuk fitoplankton berkisar pada $\mathrm{pH} 7$ 8,5 . Jika kondisi perairan bersifat asam dan basa maka akan mengganggu proses metabolisme dan respirasi beberapa jenis fitoplankton. Pada saat kondisi asam, laju pertumbuhan dinoflagellata Heterocapsa triquetra dan Teleaulax amphioxeia menurun pada rentang $\mathrm{pH}$ 6,4-6,5 sedangkan Thalassiosira pseudonana dan $T$. oceanica menurun laju pertumbuhannya pada saat kondisi basa yaitu nilai $\mathrm{pH}$ diatas 8,8 (Berge et al. 2010 \& Chen et al. 1994). Nilai pH di stasiun 1 lebih basa dibandingkan dengan stasiun lainnya karena dipengaruhi oleh berbagai faktor seperti fotosintesis alga, respirasi biota, temperatur air, dan dekomposisi senyawa organik. Ketika temperatur turun, maka $\mathrm{pH}$ semakin meningkat akibat naiknya kelarutan karbon dioksida di air (Zang et al. 2011). Sementara itu, nilai DO di perairan dipengaruhi oleh respirasi, fotosintesis, percampuran dan pergerakan massa air, dan kandungan limbah sehingga nilainya berfluktuasi. Selain $\mathrm{pH}$ dan $\mathrm{DO}$, elemen lain yang penting dalam air laut untuk mendukung pertumbuhan fitoplankton adalah nutrien yang diukur dalam penelitian ini adalah silikat, fosfat, dan nitrogen anorganik terlarut (dalam bentuk nitrat, nitrit dan amonium).

Silikat dan nitrat memiliki variasi yang mencolok sedangkan fosfat dan nitrit cenderung memiliki nilai yang hampir sama di setiap stasiun. Perbedaan kelimpahan nutrien tersebut disebabkan karena perbedaan sumber dan perbedaan karakteristik pemanfaatan masingmasing nutrien dalam proses fisika, kimia, dan biologi di lautan (Libes, 2009, Patey et al. 2008). Fosfat merupakan unsur yang cepat diserap oleh fitoplankton (Patey et al. 2008). Fitoplankton memerlukan fosfat untuk mentransfer energi ADP rendah menjadi ATP tinggi (Tomascik et al. 1997). Akibat penyerapan langsung oleh fitoplankton inilah sehingga konsentrasi fosfat cenderung rendah dengan nilai yang hampir sama di semua stasiun. Nitrit dan ammonium menunjukkan nilai yang juga hampir sama di setiap stasiun meskipun variasi ammonium dengan lonjakan nilai yang tinggi tampak di stasiun 4 dan 8 . Hal ini disebabkan kedua unsur ini mengalami transformasi dengan urutan fase ammonium-nitrit-nitrat (Patey et al. 2008). Ketika nilai ammonium tinggi maka proses transformasi belum terjadi. Setiap nitrit ataupun ammonium yang masuk ke laut akan ditransformasikan menjadi bentuk akhirnya yaitu nitrat dan menyebabkan konsentrasi kedua unsur ini rendah dan hampir sama di semua stasiun. Sebaliknya, tambahan masukan nitrat dari transformasi ammonium dan nitrit menyebabkan kelimpahan nitrat yang bervariasi di setiap stasiun.

Silikat merupakan unsur yang banyak digunakan oleh diatom sehingga perbedaan kelimpahan silikat ini juga akan menyebabkan perbedaan kelimpahan diatom yang ditemui. Kelimpahan genus Chaetoceros dan Bacteriastrum tertinggi ditemukan pada area penelitian yang konsentrasi silikatnya tinggi. Silikat dibutuhkan oleh radiolaria sponge dan silicoflagellata untuk membangun dinding sel. Dinding sel diatom membentuk struktur yang disebut frustula yang mengandung silika amorf terhidrasi dengan rumus umum $\left[\mathrm{Si}_{\mathrm{n}} \mathrm{O}_{2 \mathrm{n}}\right.$ $\left.{ }_{(\mathrm{n} \times / 2)}(\mathrm{OH})_{\mathrm{nx}}\right], \mathrm{x} \leq 4$. Proses silisifikasi melibatkan pengangkutan silikon melewati membran plasma dan kemudian melalui sitoplasma ke lokasi polimerisasi di dalam vesikula pengendapan silika (Jézéquel et al. 2000). Bentuk kimia Si yang tersedia adalah asam silikat yang tidak terdisosiasi dan dipengaruhi oleh nilai $\mathrm{pH}$. Di laut HalmaheraMaluku, nilai $\mathrm{pH}$ sebesar 7,91 sehinggga sekitar 97\% Si berada dalam bentuk DSi (silikat terlarut) dan $\mathrm{SiO}(\mathrm{OH})_{3}{ }^{-}$. Kebanyakan spesies diatom mengangkut asam silikat yang tidak terdisosiasi (Jézéquel et al. 2000).

\section{Pengaruh Konsentrasi Nutrien terhadap Kelimpahan Fitoplankton}

Identifikasi keberagaman fitoplankton menunjukkan bahwa Diatom merupakan kelompok dominan yang ditemukan di Laut Halmahera-Maluku. Hal ini disebabkan diatom dapat beradaptasi dengan lingkungan, dapat hidup 
di berbagai habitat, dan tahan terhadap berbagai kondisi. Diatom juga dapat bereproduksi dengan cepat, yaitu sebanyak tiga kali dalam 24 jam sedangkan dinoflagellata hanya mampu melakukannya satu kali dalam 24 jam pada kondisi nutrien yang sama (Praseno dan Sugestiningsih, 2000). Hal ini menunjukkan bahwa ketersediaan nutrien sangat mendukung dominansi dan kelimpahan diatom di lokasi penelitian ini.

Hasil lain dari penelitian ini memperlihatkan bahwa Chaetoceros dan Bacteriastrum ditemukan dengan jumlah terbanyak di perairan Halmahera-Maluku. Ukuran tubuh dan kemampuan metabolisme Chaetocheros dan Bacteriastrum menjadi kunci utama keberhasilan jenis ini dalam mendominasi populasi. Menurut Tan dan Ransangan 2017, Chaetoceros dan Bacteriastrum lebih mampu untuk menyerap nutrien karena ukurannya lebih kecil dibandingkan dengan diatom yang berukuran lebih besar. Ukuran kecil ini menyebabkan total area permukaan Diatom menjadi lebih tinggi dibandingkan rasio volume sehingga dapat menyerap lebih banyak nutrien per unit biomasa dengan laju yang tinggi. Selain itu, fitoplankton berukuran kecil memiliki metabolisme sel yang lebih rendah sehingga dapat bertahan pada konsentrasi nutrien yang rendah (Tan and Ransangan 2017). Pernyataan ini diperkuat oleh hasil penelitian sebelumnya yang menyatakan bahwa secara umum Chaetoceros memiliki kelimpahan tertinggi di perairan Indonesia (Thoha dan Rachman, 2013).

Setiap fitoplankton memiliki perbedaan kemampuan dalam penyerapan nutrien dan perbedaan kondisi lingkungan yang khusus untuk tumbuh. Berdasarkan analisis hubungan antara fitoplankton dan nutrien di laut HalmaheraMaluku memperlihatkan bahwa variasi konsentrasi silikat mempengaruhi kelimpahan Thalassiothrix, Bacteriastrum, Skletonema, dan Hemiaulus. Hal ini disebabkan karena Thalassiothrix, Bacteriastrum, Skletonema, dan Hemiaulus merupakan jenis diatom yang membutuhkan silikat untuk membangun dinding sel mereka. Skeletonema akan mendominasi pada kondisi silikat lebih tinggi dari $2 \mu \mathrm{mol} / \mathrm{L}$ (Hu et al. 2011) dan lebih toleran terhadap kondisi eutrofikasi (Abdalla et al. 1995). Selain itu, dari penelitian yang dilakukan oleh Tan and Ransangan (2017), Skeletonema menunjukkan korelasi positif dengan $\mathrm{PO}_{4}-\mathrm{P}$ sedangkan Bacteriastrum berkorelasi positif dengan DIN dan rasio N:P. Akan tetapi, penelitian ini tidak menunjukkan hubungan tersebut karena kondisi lingkungan seperti salinitas yang berbeda antara lokasi penelitian dengan literatur.

Chaetoceros, Nitzchia, Climacodium, Ceratium, dan Prorocentrum memiliki korelasi positif yang signifikan terhadap amonium. Hal ini mengisyaratkan jenis Diatom dari perairan Halmahera-Maluku tersebut mampu menggunakan amonium sebagai sumber nitrogen. Tiap jenis fitoplankton memiliki kemampuan yang berbeda dalam mendapatkan nitrogen untuk metabolismenya. Beberapa jenis fitoplankton hanya mampu memanfaatkan nitrogen dari unsur sederhana seperti nitrat dan jenis lainnya mampu menyerap nitrogen dari unsur yang lebih kompleks seperti ammonia dan urea (Patey et al. 2008). Karthikeyan et al. pada tahun 2012 melakukan penelitian mengenai pertumbuhan dari diatom Chaetoceros curvisetus and C. simplex terhadap sumber nitrogen yang berbeda. Hasilnya menyebutkan $C$. curvisetus tumbuh cepat pada nitrat sedangkan $C$. simplex tumbuh cepat pada urea akan tetapi kedua spesies tersebut tumbuh lambat pada amonium. Hal ini disebabkan oleh toksisitas atau pengasaman media kultur selama pertumbuhan akibat berlebihnya konsentrasi nitrogen (Xin et al. 2010). Sebaliknya, konsentrasi amonium tinggi akan menghambat atau mengurangi penyerapan nitrat oleh beberapa jenis fitoplankton sehingga menghasilkan perkembangan fitoplankton yang menurun (Tan and Rangsangan 2017). Di laut Halmahera-Maluku dengan kondisi ammonium tinggi diduga menyebabkan kelimpahan Thalassiosira dan Guinardia rendah.

Berdasarkan pengamatan dalam penelitian ini, fosfat merupakan nutrien yang mempengaruhi kelimpahan Coscinodiscus, Lauderia, Protoperidinium, Rhizosolenia, dan Eucampia dan nitrat mempengaruhi kelimpahan Alexandrium dan Dinophysis. Hal ini mneunjukkan bahwa fluktuasi fosfat atau nitrat akan mempengaruhi jumlah jenis-jenis fitoplankton tersebut. Jenis-jenis fitoplankton tersebut juga dipengaruhi oleh konsentrasi nitrat dan fosfat di perairan lain. Coscinodiscus berkorelasi positif $(\mathrm{p}<0,05)$ dengan $\mathrm{PO}_{4}-\mathrm{P}$ di perairan Teluk Marudu, Malaysia sementara Rhizosolenia berkorelasi positif $(\mathrm{p}<0,05)$ dengan rasio N:P (Tan and Ransangan 2017). Hubungan antara parameter fisika kimia dengan spesies fitoplankton di Perairan Saudi Arabia menyebutkan bahwa Rhizosolenia shrubsolei berkorelasi positif dengan amonium sedangkan Protoperidinium berkorelasi positif amonium dan 
fosfat (El Gammal et al. 2017). Di lain sisi, Eucampia menyukai kondisi rasio N:P > 100 dan dapat tumbuh pada kondisi nutrien yang terbatas (Hori et al. 1998, Nishikawa et al. 2009). Pengaruh nitrat terhadap beberapa jenis fitoplankton juga ditemukan dalam beberapa studi lain. Alexandrium tamarense dapat beradaptasi pada konsentrasi nitrat dengan rentang yang lebar (Fauchot et al. 2005) dan Dinophysis acuminata dapat hidup pada rentang konsentrasi nitrat 0,010 - $0,154 \mathrm{mg} / \mathrm{L}$ (The University of British Columbia 2018).

Kelimpahan suatu nutrien di perairan mempengaruhi dominasi fitoplankton sehingga informasi mengenai rasio komposisi antar nutrien diperlukan untuk mengetahui faktor pembatas pertumbuhan (Davidson et al. 2012). Rasio N:P = 16:1 secara luas digunakan untuk menyimpulkan nutrien yang membatasi pertumbuhan fitoplankton, dimana rasio $<16: 1$ menunjukkan keterbatasan nitrogen dan rasio $>16: 1$ menunjukkan keterbatasan fosfor (Davidson et al 2014). N dan P ini diwakili dengan DIN dan DIP dan rata-rata nilai DIN:DIP pada penelitian ini memiliki nilai lebih kecil dari 16 yaitu sebesar 12,61. Hasil ini menunjukkan bahwa nitrogen sebagai pembatas pertumbuhan fitoplankton di laut Halmahera-Maluku. Wang et al. (2006) menyatakan bahwa rasio $\mathrm{N}: \mathrm{P}$ mempengaruhi komposisi fitoplankton, jika nitrogen yang menjadi faktor pembatas maka fitoplankton yang dominan berasal dari kelompok diatom (bacillariophyceae). Nitrogen lebih sering dijadikan faktor pembatas di laut dikarenakan terhambatnya fiksasi $\mathrm{N}$ oleh garam di air laut (Marino et al. 2002).

Komposisi nutrien lain yang biasa digunakan untuk mengetahui pembatas pertumbuhan fitoplankton adalah rasio DIN:Si. Rata-rata DIN:Si di laut Halmahera-Maluku memiliki nilai lebih kecil dari 1 yaitu sebesar 0,259 sehingga ini menunjukkan bahwa silikat berlimpah dibandingkan dengan DIN. Dengan demikian, silikat tidak akan membatasi pertumbuhan diatom. Hasil rasio $\mathrm{N}: \mathrm{Si}$ yang rendah menunjukkan bahwa diatom mendominasi kelimpahan fitoplankton di lokasi tersebut. Gilpin et al (2004), menyatakan bahwa rasio N:Si mengubah struktur komunitas diatomdinoflagellata, dengan semakin rendah rasio $\mathrm{N}: \mathrm{Si}$ maka menyebabkan kelimpahan diatom lebih tinggi daripada kelimpahan dinoflagellata. Hasil penelitian di laut Halmahera-Maluku selaras dengan pernyataan tersebut.

\section{Kesimpulan}

Dari hasil penelitian ini setiap fitoplankton di laut Halmahera-Maluku memiliki preferensi yang berbeda terhadap nutrien. Amonium merupakan nutrien yang berkorelasi positif dengan kelimpahan fitoplankton yang didominasi kelompok bacillariophyceae (Chaetoceros). Nitrogen merupakan faktor pembatas pertumbuhan fitoplankton karena rasio $\mathrm{N}: \mathrm{P}<16$.

\section{Persantunan}

Penelitian ini merupakan hasil riset Joint Research Cruise LIPI-IOCAS tahun 2015. Penulis mengucapkan terima kasih kepada Koordinator Penelitian Adhitya K. Wardhana, M.Sc dan Dewi Surinati, M.Si serta rekan peneliti dan teknisi Pusat Penelitian Oseanografi LIPI sehingga penelitian ini dapat terlaksana dengan baik

\section{Daftar Pustaka}

Abdalla, R. R., Zaghloul, F. A. and Hussein, N. R. 1995. A statistical modelling of phytoplankton eutrophication in the Eastern Harbour, Alexandria, Egypt. Bulletin of the National Institute of Oceanography and Fisheries (Egypt) 21(1): 125-146.

Berge, T., N. Daugbjerg, B.B. Andersen, and P.J. Hansen. 2010. Effect of lowered $\mathrm{pH}$ on marine phytoplankton growth rates. Marine Ecology Progress Series 416: 79-91.

Chen, C.Y., and E.G. Durbin. 1994. Effects of pH on the growth and carbon uptake of marine phytoplankton. Marine Ecology Progress Series 109: 83-94.

Chen, C.T.A. 2007. Nutrient cycling in the oceans; in: "Oceanography," ed. by J.C.J. Nihoul and C.T.A. Chen, in Encyclopedia of Life Support Systems (EOLSS), Developed under the Auspices of the UNESCO, Eolss Publishers, Oxford, UK, ISBN: 978-1-905839-62-9 e-Book,Vol. 1, 331-343.

Davidson, K., R.J. Gowen, P.J. Harrison, L.E. Fleming, P. Hoagland, and G. Moschonas. 2014. Anthropogenic nutrients and harmful 
algae in coastal waters. Journal of Environmental Management 146: 206-216.

Davidson, K., R.J. Gowen, P. Tett, E. Bresnan, P.J. Harrison, A. McKinney, S. Milligan, D.K. Mills, J. Silke, and A.M. Crooks. 2012. Harmful algal blooms: how strong is the evidence that nutrient ratios and forms influence their occurrence? Estuarine, Coastal and Shelf Science 115: 399-413.

Davis, CC. 1955. The marine and freshwater plankton. Michigan State University Press. USA. 426 pp.

El Gammal, M.A.M., M. Nageeb, and S. AlSabeb. 2017. Phytoplankton abundance in relation to the quality of the coastal water Arabian Gulf, Saudi Arabia. Egyptian Journal of Aquatic Research 43:275-282.

Fauchot, J., M. Levasseur, S. Roy, R. Gagnon and M. Weise. 2005. Environmental Factors Controlling Alexandrium tamarense (Dinophyceae) growth rate during a red tide event in the St. Lawrence estuary (Canada). Phycological Society of America 41: 263-272.

Gilpin, L.C., K. Davidson, and E. Roberts. 2004. The influence of changes in nitrogen: silicon ratios on diatom growth dynamics. Journal of Sea Research 51: 21-35.

Hori, Y., K. Miyahara, S., Nagai, K. Tsujino, M. Nakajima, K. Yamamoto, Y. Yoshida, N. Araki, and Y. Sakai. 1998. Relationships between the dominant phytoplankton and DIN:DIP ratios in Osaka Bay and HarimaNada. Nippon Suisan Gakkaishi 64 (2): 243248.

Howarth, R.W., and R. Marino. 2006. Nitrogen as the limiting nutrient for eutrophication in coastal marine ecosystems: evolving views over three decades. Limnology and Oceanography 51: 364-376.

Hu, H., J. Zhang, and W. Chen. 2011. Competition of bloom-forming marine phytoplankton at low nutrient concentrations. Journal of Environmental Science 23(40): 656-663.

Jézéquel, V.M., M. Hildebrand, and M.A. Brzezinski. 2000. Review Silicon Metabolism In Diatoms: Implications For Growth. Journal of Phycology 36: 821-840.

Karthikeyan,P., P. Sampathkumar, K. Manimaran, and L. Rameshkumar. 2013. Growth and nutrient removal properties of the diatoms, Chaetoceros curvisetus and C. simplex under different nitrogen sources. Applied Water Science 3:49-55.
Koike, I., H. Ogawa, T. Nagata, R. Fukuda, and H. Fukuda. 2001. Silicate to Nitrate Ratio of the Upper Sub-Arctic Pacific and the Bering Sea Basin in Summer: Its Implication for Phytoplankton Dynamics. Journal of Oceanography 57: $253-260$.

Libes, S. 2009. Introduction to Marine Biogeochemistry.Second Edition. Academic Press, 925pp.

Li, Y., A.M. Waite, G. Gal, and M.R. Hipsey. 2012. Do phytoplankton nutrient ratios reflect patterns of water column nutrient ratios? A numerical stoichiometric analysis of Lake Kinneret. Procedia Environmental Sciences 13:1630-1640.

Marino, R., F. Chan, R.W. Howarth, M. Pace, and G.E. Likens. 2002. Ecological and biochemical interactions constrain planktonic nitrogen fixation in estuaries. Ecosystems 5: 719-725.

Millero, F.J. 2006. Chemical oceanography. Third edition. Taylor and Francis Group. CRC Press. New York.530p.

Nishikawa, T., K. Tarutani, and T. Yamamoto 2009. Nitrate and phosphate uptake kinetics of the harmful diatom Eucampia zodiacus Ehrenberg, a causative organism in the bleaching of aquacultured Porphyra thalli. Harmful Algae 8 (3): 513-517.

Omura, T., M. Iwataki, V. M. Borja, H. Takayama, and Y. Fukuyo. 2012. Marine Phytoplankton of the Western Pacific. Kouseisha Kouseikaku Co., Ltd. Japan. 160 pp.

Patey, M. D., M. J. A. Rijkenberg, P. J. Statham, M. C. Stinchcombe, E. P. Achterberg, and M. Mowlem. 2008. Determination of Nitrate and Phosphate in Sea Water at Nano Molar Concentration. Trends in Analytical Chemistry 27 (2): 169-182.

Praseno, D. P. dan Sugestiningsih. 2000. Retaid di Perairan Indonesia. P3O-LIPI.Jakarta. Hal: 234.

Pusat Penelitian Oseanografi. 2005. Laporan Akhir Ekspedisi Halmahera 2005 Prospek Pengembangan Sumberdaya Laut di Kawasan Barat Pulau Halmahera dan Pulau Morotai. Pemerintah Provinsi Maluku Utara Bekerjasama dengan Pusat Penelitian Oseanografi - Lembaga Ilmu Pengetahuan Indonesia, Jakarta.

Riley, J. P., and R. Chester. 1971. Introduction to marine chemistry. Academic Press, London and New York. 
Sediadi, A. 2004. Efek Upwelling Terhadap Kelimpahan dan Distribusi Fitoplankton di Perairan Laut Banda dan Sekitarnya. Makara Sains 8 (2): 43-51.

Strickland, J.D.H. and T. R. Parsons, 1972. A Practical Handbook of Seawater Analysis, Bulletin 167 (Second edition). Fisheries Research Board of Canada. Ottawa. 310 pp.

Struyf, E., A. Smis, S. Van Damme, P. Meire, and D.J. Conley. 2009. The global biogeochemical silicon cycle. Silicon 1207 213.

Tan, K.S. and J. Ransangan. 2017. Effects of nutrients and zooplankton on the phytoplankton community structure in Marudu Bay. Estuarine, Coastal and Shelf Science 194: 16-29.

Tangke, U., J.C. Karuwal, M. Zainuddin, dan A. Mallawa. 2015. Sebaran Suhu Permukaan Laut dan Klorofil-A Pengaruhnya Terhadap Hasil Tangkapan Yellowfin Tuna (Thunnus Albacares) Di Perairan Laut Halmahera. Jurnal IPTEKS PSP 2 (3): 248-260.

Taylor, F.J.R.. 1994. Reference Manual Taxonomic Identification of Phytoplankton with Reference to HAB Organisms. ASEANCanada Cooperative Programme on Marine Science Workshop on the Taxonomy of Phytoplankton and Harmful Algal BloomOrganisms Hosted by LIPI, Jakarta. 568 p.

The University of British Columbia. 2018. The Phytoplankton Encyclopaedia Project. https://www.eoas.ubc.ca/research/phytoplank ton/index.html. Diakses tanggal 15 Februari 2018.

Thoha, H dan A. Rachman. 2013. Kelimpahan dan Distribusi Spasial Komunitas Plankton di
Perairan Kepulauan Banggai. Jurnal Ilmu dan Teknologi Kelautan Tropis 5 (1): 145-161.

Tomascik, T., A.J. Mah, A. Nontji, and M.K. Moosa. 1997. The Ecology of the Indonesian Seas. Part Two. The Ecology of Indonesia Series Vol VIII. Periplus Editions. Singapore. $1388 p$.

Turner, R.E. 2002. Element ratios and aquatic food webs. Estuaries 25: 694-703.

Wang, Z., Y. Qi, J. Chen, N. Xu, and Y. Yang. 2006. Phytoplankton abundance, community structure and nutrients in cultural areas of Daya Bay, South China Sea. Journal of Marine Systems 62: 85-94.

Wickstead, J.H. 1965. An Introduction to Study of Tropical Plankton. Hutchinson Tropical Monographs. London. $160 \mathrm{p}$.

Xin, L., H. Hong-ying, G. Ke, S. Ying-xue. 2010. Effects of different nitrogen and phosphorus concentrations on the growth, nutrient uptake, and lipid accumulation of a freshwater micro alga Scenedesmus sp. Bioresource Technology 101:5494-5500.

Yamaji, I.E. 1976. Illustration of the Marine Plankton of Japan. Hoikusha, Osaka, Japan. $618 \mathrm{pp}$.

Zang, C., S. Huang, M. Wu, S. Du, M. Scholz, F. Gao, C. Lin, Y. Guo, and Y. Dong. 2011. Comparison of Relationships Between $\mathrm{pH}$, Dissolved Oxygen and Chlorophyll a for Aquaculture and Non-aquaculture Waters. Water Air Soil Pollut 219:157-174.

Zhu, W., L. Wan, and L.F. Zhao. 2010. Effect of nutrient level on phytoplankton community structure in different water bodies. Journal of Environmental Science 22: 32-39. 